\title{
Pharmacological basis for antihypertensive effects of intravenous labetalol
}

\author{
D. A. RICHARDS, ${ }^{1}$ B. N. C. PRICHARD, A. J. BOAKES, \\ J. TUCKMAN, AND E. J. KNIGHT ${ }^{2}$
}

From the Department of Clinical Pharmacology, University College Hospital, Medical School, London

Labetalol $1.5 \mathrm{mg} / \mathrm{kg}$ administered intravenously to normal subjects in the supine position produced an immediate mean fall in systolic (16\%) and diastolic (25\%) blood pressure with a concomitant increase in heart rate (12\%). After graded exercise, intravenous labetalol inhibited increases in heart rate and blood pressure.

Isoprenaline log dose response curves of increase in heart rate and reduction in diastolic pressure after intravenous labetalol shifted to the right in a parallel manner compared with pre-labetalol response curves suggestive of competitive antagonism at beta-adrenoceptor sites. Similarly, phenylephrine dose response curves of increase in systolic pressure before and after intravenous labetalol were suggestive of competitive antagonism at alpha-adrenoceptor sites. The ratio of relative potency alpha: beta adrenoceptor antagonism after intravenous labetalol was approximately $1: 7$, whereas in the same subjects after oral labetalol the ratio was approximately $1: 3$ as previously reported.

Using the inhibition of isoprenaline tachycardia to estimate the potency of the beta-adrenoceptor antagonism of labetalol relative to that of propranolol the potency ratio was $1: 6$. However, using inhibition of Valsalva tachycardia as the index, the estimated ratio was approximately $1: 3$. Estimates of relative potency using inhibition of tilt tachycardia were complicated by the additional effects upon blood pressure after labetalol not seen after propranolol.

Labetalol produced adrenoceptor blockade at both alpha and beta sites in man sufficient to explain its therapeutic antihypertensive effect.

Labetalol is a compound possessing combined alpha and beta adrenoceptor antagonist properties (Farmer et al., 1972). Consequently it has been assessed in clinical practice as an antihypertensive agent. Prichard et al. (1975) and Koch (1976) have shown that labetalol administered intravenously to hypertensive patients exerts an antihypertensive effect with little effect upon either heart rate or cardiac output. Similar results were obtained by Edwards and Raftery (1976) where labetalol was administered orally on a chronic basis in hypertensive patients. Rosei et al. (1975) and Pearson and Havard (1976) administered labetalol intravenously in doses of 1.0 to $2.0 \mathrm{mg} / \mathrm{kg}$ to reduce blood pressure in patients with severe and malignant hypertension. A dose of $1.5 \mathrm{mg} / \mathrm{kg}$ was particularly effective in

\footnotetext{
${ }^{1}$ Present address: Allen and Hanburys Research Ltd., Ware, Hertfordshire SG12 0DJ.

${ }^{2}$ Present address: Watford General Hospital, Vicarage Road, Watford.

Received for publication 6 August 1976
}

reducing blood pressure. This report concerns a study of intravenous labetalol which was used at a dose of $1.5 \mathrm{mg} / \mathrm{kg}$ in order to determine the pharmacological properties of the drug which might be contributory to its therapeutic antihypertensive effect. We also report detailed data of a study previously reported in summarised form (Boakes et al., 1971).

\section{Method}

Six informed healthy male volunteers who had previously taken part in a similar study involving oral labetalol (Richards et al., 1976) consented to take part. Their ages ranged from 27 to 39 years and weights from 60 to $84 \mathrm{~kg}$. Blood pressure was measured with a London School of Hygiene and Tropical Medicine sphygmomanometer (Rose et al., 1964) and heart rate was taken from a continuously running electrocardiograph. Each subject rested in the supine position for 15 minutes, then heart 
rate and blood pressure were measured at minute intervals for a period of 5 minutes. The subjects then transferred to a bicycle ergometer (Elema) and readings were taken for a further 5 minutes. The subjects exercised at increasing work loads of 50, 100 , and 150 Watts for 2 minutes at each level; blood pressures were recorded at minute intervals throughout. The subjects were returned to the supine position and rested for a period of 30 minutes during which a left forearm vein was cannulated using a butterfly needle, and heparinised saline was infused throughout in order to maintain patency of the intravenous needle. During the last 5 minutes of this rest period, observations of heart rate and blood pressure were recorded at minute intervals.

Each subject was then infused with phenylephrine and isoprenaline in random order, 3 receiving phenylephrine first; the remainder isoprenaline first. Phenylephrine was infused at increasing doses in order to plot a cumulative log dose response curve for increases in systolic pressure. The starting dose of phenylephrine was $100 \mu \mathrm{g} /$ minute for 4 minutes followed by $200 \mu \mathrm{g} /$ minute for 4 minutes, the final dose being $400 \mu \mathrm{g} /$ minute. Measurements of heart rate and blood pressure were made throughout this period.

When each subject had rested for 30 minutes after the initial infusion, the alternate drug was infused. Isoprenaline was started at $2 \mu \mathrm{g} /$ minute for 4 minutes followed by $4 \mu \mathrm{g} /$ minute, with the final dose being $8 \mu \mathrm{g} /$ minute each for 4 -minute periods. As before, heart rate and blood pressure were measured throughout. After a delay of 30 minutes each subject received intravenous labetalol 1.5 $\mathrm{mg} / \mathrm{kg}$ body weight (average dose $113 \mathrm{mg}$ ) injected over 1 minute. Heart rate and blood pressure were recorded throughout the subsequent 15 minutes at minute intervals. Phenylephrine and isoprenaline were then reinfused in random order. Following labetalol on these occasions, the doses of both phenylephrine and isoprenaline were adjusted to produce changes similar to those recorded in the predrug period. After a rest period of 30 minutes after the final infusion, each subject was again exercised at a similar work level as in the predrug period.

More detailed studies were carried out in 3 other subjects. The laboratory procedures were similar to those described above. Each subject received an infusion of isoprenaline followed by intravenous labetalol in doses of 10,40 , and $160 \mathrm{mg}$, and propranolol in a dose of $10 \mathrm{mg}$ each administered on different occasions. Each dose of drug was given over a period of 5 minutes and was followed 20 minutes later with the repeat infusion of isoprenaline. On separate occasions phenylephrine was infused but here only doses of 40 and $160 \mathrm{mg}$ labetalol were administered. Before the administration of labetalol, each subject had been tilted at $80^{\circ}$ for a period of 2 minutes. This was followed by the Valsalva manoeuvre where a column of mercury was maintained at $40 \mathrm{mmHg}$ for 20 seconds. Measurements of blood pressure and heart rate were recorded throughout. These procedures were repeated 6 minutes after administration of each intravenous dose of labetalol and propranolol in each subject.

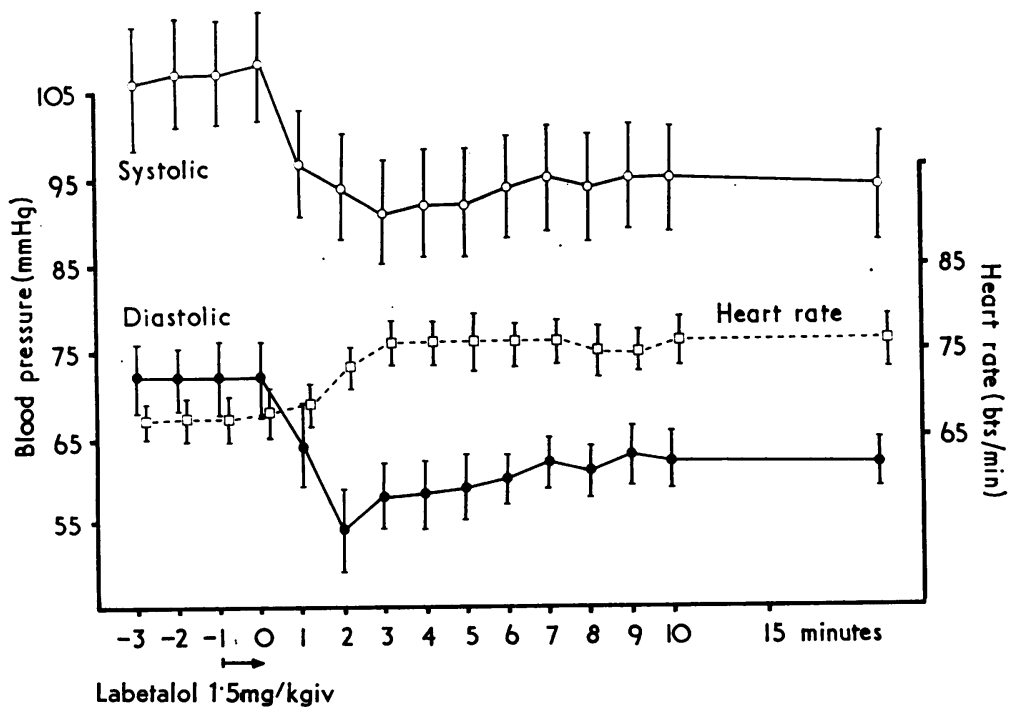

Fig. 1 Effect of intravenous labetalol $(1.5 \mathrm{mg} / \mathrm{kg})$ on mean blood pressure and heart rate in 6 normotensive men. 


\section{Results}

\section{EFFECTS OF LABETALOL UPON HEART RATE AND BLOOD PRESSURE, SUPINE AND SITTING}

Before labetalol administration in 6 subjects in the supine position the mean $( \pm$ SEM) resting heart rate was $68(4.3)$ beats/minute; systolic pressure 108 (6.5) $\mathrm{mmHg}$ and diastolic pressure $72(3.9) \mathrm{mmHg}$. Within one minute of labetalol $(1.5 \mathrm{mg} / \mathrm{kg})$ administration there was a reduction in both systolic and diastolic blood pressure together with a concomitant increase in heart rate. The maximum reduction in systolic pressure was 16 per cent $(17 \mathrm{mmHg})$ and diastolic pressure 25 per cent $(18 \mathrm{mmHg}$ ) occurring within 3 minutes of the completion of the labetalol injection. The increase in heart rate was maximal 3 minutes after the completion of the drug administration and at maximum was 12 per cent ( 8 beats $/ \mathrm{min}$ ) above the preinjection value (Fig. 1). Of the 6 subjects, 4 spontaneously mentioned that they experienced a feeling of warmth and/or flushing immediately after the administration of labetalol.

Before labetalol administration and immediately before exercise mean heart rates were 68 (3.3) supine, and $79(5.2)$ beats/minute in the sitting position. Blood pressures were $104(4 \cdot 2) / 71(2 \cdot 6)$ $\mathrm{mmHg}$ and $97(4.6) / 67(4.0) \mathrm{mmHg}$, respectively. The difference between supine and sitting systolic pressure was significant $(P<0.05)$. One hundred minutes after labetalol the mean heart rates were $76(4.6)$ beats/minute supine and $82(2.9)$ beats/ minute sitting and comparable blood pressures were $108(2.6) / 71(1.8) \mathrm{mmHg}$ and $89(4.5) / 59(4.3)$ $\mathrm{mmHg}$. Again the difference between supine and sitting systolic pressures was significant $(P<0.05)$. In addition systolic and diastolic pressures (sitting) after labetalol were significantly different $(P<0.05)$ from the values before administration of the drug.
EFFECTS OF LABETALOL UPON EXERCISEINDUCED CHANGES IN HEART RATE

AND BLOOD PRESSURE

The mean values for heart rate blood pressure and mean arterial pressure after graded exercise before and after labetalol (Table 1) showed that the drug inhibited the exercise-induced increases in heart rate and systolic blood pressure at each level of exercise $(P<0.001)$ (Fig. 2). In addition, labetalol reduced diastolic pressure at each exercise level so that at the highest exercise level (150 Watts) the mean arterial pressure was $73(2.4) \mathrm{mmHg}$ compared with $100(3.4) \mathrm{mmHg}$ before labetalol was administered $(P<0.001)$.

\section{EFFECTS UPON INCREASING DOSES OF} INTRAVENOUS ISOPRENALINE

The mean predrug increase in heart rate was 58 $(7.4)$ beats/minute and the reduction in diastolic pressure $36(4.3) \mathrm{mmHg}$ after the $8 \mu \mathrm{g} /$ minute dose of the cumulative isoprenaline infusion (Table 2). In 3 subjects, isoprenaline was reinfused 15 minutes after labetalol $(1.5 \mathrm{mg} / \mathrm{kg})$ administration and in the other 3 subjects after 60 minutes. Comparison of the antagonist effect of labetalol in the two groups indicated that there were no significant differences relating to order of administration so that all individual values were used to calculate the mean post-drug values (Table 2). The log dose isoprenaline response curves in respect of increases in heart rate before and after labetalol (Fig. 3) show that there was a parallel shift to the right after labetalol. These curves were plotted using the mean response at each dose level, and from regression lines an estimate of dose ratio was made. After labetalol the dose of isoprenaline had to be increased by a mean of 26.2 times in order to induce similar increases in heart rate. This is defined as the isoprenaline dose ratio.

The log dose isoprenaline response curve for

Table 1 Effects of graded exercise on heart rate and blood pressure before and after intravenous labetalol $(n=6)$

\begin{tabular}{|c|c|c|c|c|c|c|}
\hline & \multicolumn{3}{|l|}{ Before drug } & \multicolumn{3}{|c|}{ After labetalol } \\
\hline & $\begin{array}{l}\text { Heart rate } \\
\text { (beats/min) } \\
( \pm S E)\end{array}$ & $\begin{array}{l}\text { Blood pressure } \\
(\operatorname{mmHg}) \\
( \pm S E)\end{array}$ & $\begin{array}{l}\text { Mean arterial } \\
\text { pressure (mmHg) } \\
( \pm S E)\end{array}$ & $\begin{array}{l}\text { Heart rate } \\
\text { (beats/min) } \\
( \pm S E)\end{array}$ & $\begin{array}{l}\text { Blood pressure } \\
(\operatorname{mm} H g) \\
( \pm S E)\end{array}$ & $\begin{array}{l}\text { Mean arterial } \\
\text { pressure (mam } H g) \\
( \pm S E)\end{array}$ \\
\hline $\begin{array}{l}\text { Pre-exercise } \\
\text { Exercise } 50 \text { Watts } \\
\text { Exercise } 100 \text { Watts } \\
\text { Exercise } 150 \text { Watts }\end{array}$ & $\begin{array}{l}79 \\
(5 \cdot 2) \\
93 \\
(7 \cdot 0) \\
112 \\
(5 \cdot 0) \\
132 \\
(9 \cdot 6)\end{array}$ & $\begin{array}{l}97 / 67 \\
(4 \cdot 6) /(4 \cdot 0) \\
108 / 64 \\
(4 \cdot 5) / 2 \cdot 7) \\
124 / 68 \\
(6 \cdot 7) /(2 \cdot 4) \\
154 / 73 \\
(9 \cdot 4) /(1 \cdot 9)\end{array}$ & $\begin{array}{l}77 \\
(3 \cdot 4) \\
79 \\
(3 \cdot 6) \\
86 \\
(2 \cdot 7) \\
100 \\
(3 \cdot 4)\end{array}$ & $\begin{array}{l}82 \\
(2 \cdot 9) \\
93 \\
(4 \cdot 0) \\
108 \\
(3 \cdot 7) \\
120 \star \star \\
(3 \cdot 8)\end{array}$ & $\begin{array}{l}\star \star 89 / 59 \star \\
(4 \cdot 5) /(4 \cdot 3) \\
\star \star 85 / 57 \star \\
(3 \cdot 5) /(3 \cdot 3) \\
\star \star 94 / 57 \star \star \\
(4 \cdot 7) /(3.9) \\
\star \star 112 / 54 \star \star \\
(6 \cdot 7) / 1 \cdot 7)\end{array}$ & $\begin{array}{l}69 \star \\
(2 \cdot 7) \\
66 \star \star \\
(2 \cdot 8) \\
69 \star \star \\
(3 \cdot 6) \\
73 \star \star \\
(2 \cdot 4)\end{array}$ \\
\hline
\end{tabular}

$\star P<0.05$ differences from predrug values; $\star \star P<0.001$ differences from predrug values. 


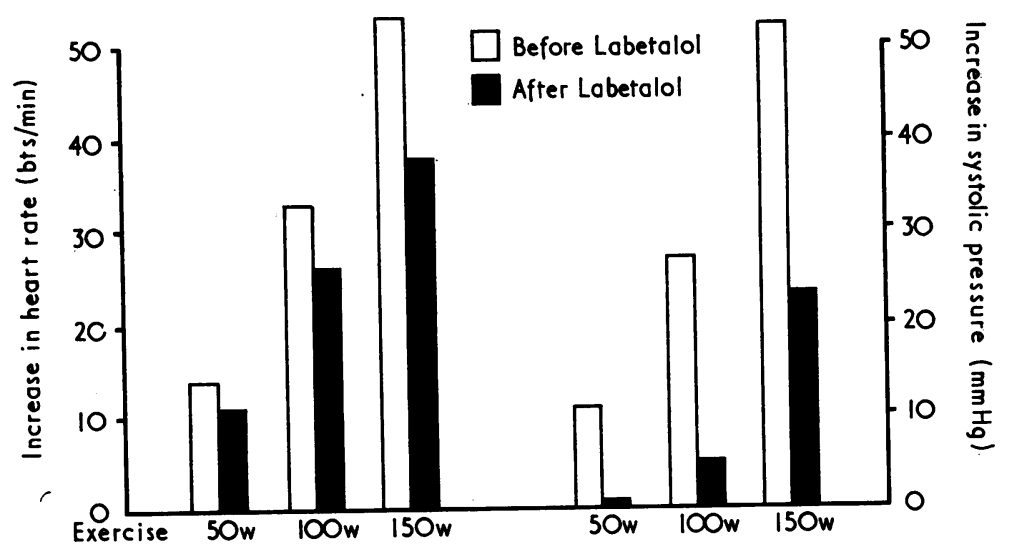

Fig. 2 Effects of intravenous labetalol $(1.5 \mathrm{mg} / \mathrm{kg})$ on exercise induced changes in heart rate and blood pressure $(n=6)$.

reduction in diastolic pressure before and after labetalol (Fig. 4) showed a parallel shift to the right after the drug, and the dose of isoprenaline was increased by a mean of 23.8 times the dose administered before the drug in order to induce similar reductions in diastolic pressure.

More detailed studies in 3 subjects showed that after graded doses of labetalol there were increasing shifts to the right of the log dose isoprenaline response curves (Fig. 5). After labetalol $10 \mathrm{mg}$ the isoprenaline dose ratio was $3 \cdot 8$, after $40 \mathrm{mg} 6 \cdot 0$, and after $160 \mathrm{mg} 37 \cdot 4$.
The administration of propranolol $10 \mathrm{mg}$ also resulted in a parallel shift of the isoprenaline dose response curve and in this case the isoprenaline dose ratio was $13 \cdot 2$.

\section{EFFECTS OF INCREASING DOSES OF}

INTRAVENOUS PHENYLEPHRINE

As with isoprenaline, phenylephrine was started 15 minutes after labetalol $(1.5 \mathrm{mg} / \mathrm{kg})$ in 3 subjects and 60 minutes after in the remaining 3 subjects.

As before, we examined the data to see if the order of administration and time difference significantly

Table 2 Mean isoprenaline- and phenylephrine-induced changes before and after $1.5 \mathrm{mg} / \mathrm{kg}$ labetalol intravenously ( $\mathrm{n=6}$ )

\begin{tabular}{|c|c|c|c|c|c|}
\hline & \multirow[t]{2}{*}{ Dose/min } & \multicolumn{2}{|l|}{ Before labetalol } & \multicolumn{2}{|l|}{ After labetalol } \\
\hline & & Heart rate (beats/min) & Blood pressure (mmHg) & Heart rate (beats/min) & Blood pressure $(\mathrm{mmHg})$ \\
\hline \multicolumn{2}{|l|}{ Pre-isoprenaline } & $\begin{array}{l}70 \\
(7 \cdot 6)\end{array}$ & $\begin{array}{l}103 / 69 \\
(8 \cdot 2) /(3 \cdot 7)\end{array}$ & $\begin{array}{l}73 \\
(6 \cdot 8)\end{array}$ & $\begin{array}{l}102 / 66 \\
(8.9) /(3.1)\end{array}$ \\
\hline \multirow[t]{4}{*}{ Isoprenaline } & $\begin{array}{l}2 \mu \mathrm{g} \\
4 \mu \mathrm{g} \\
8 \mu \mathrm{g}\end{array}$ & $\begin{array}{l}84 \\
(8 \cdot 4) \\
110 \\
(8 \cdot 2) \\
128 \\
(7 \cdot 3)\end{array}$ & $\begin{array}{l}109 / 56 \\
(8 \cdot 9) /(2 \cdot 4) \\
110 / 39 \\
(11 \cdot 6) /(1 \cdot 5) \\
110 / 33 \\
(10 \cdot 0) /(2 \cdot 0)\end{array}$ & & \\
\hline & $32 \mu \mathrm{g}$ & & & $\begin{array}{l}75 \\
(3 \cdot 7)\end{array}$ & $\begin{array}{l}105 / 56 \\
(3 \cdot 1) /(3 \cdot 8)\end{array}$ \\
\hline & $64 \mu \mathrm{g}$ & & & $\begin{array}{l}95 \\
(2 \cdot 6)\end{array}$ & $\begin{array}{l}93 / 40 \\
(6.9) /(3.3)\end{array}$ \\
\hline & $128 \mu \mathrm{g}$ & & & $\begin{array}{l}112 \\
(6.9)\end{array}$ & $\begin{array}{l}95 / 33 \\
(8 \cdot 3) /(2 \cdot 7)\end{array}$ \\
\hline \multicolumn{2}{|c|}{ Pre-phenylephrine } & 63 & $\begin{array}{l}106 / 74 \\
(7 \cdot 2) /(4 \cdot 0)\end{array}$ & $\begin{array}{l}70 \\
(6.5)\end{array}$ & $\begin{array}{l}95 / 62 \\
(6 \cdot 3) /(3 \cdot 2)\end{array}$ \\
\hline \multirow[t]{4}{*}{ Phenylephrine } & $\begin{array}{l}100 \mu \mathrm{g} \\
200 \mu \mathrm{g}\end{array}$ & $\begin{array}{l}(0 \cdot 8) \\
55 \\
(4 \cdot 1) \\
47 \\
(2 \cdot 2)\end{array}$ & $\begin{array}{l}125 / 91 \\
(5 \cdot 2) /(3 \cdot 5) \\
140 / 99 \\
(5 \cdot 0) /(4 \cdot 6)\end{array}$ & & \\
\hline & $400 \mu g$ & $\begin{array}{l}40 \\
(0 \cdot 5)\end{array}$ & $\begin{array}{l}175 / 118 \\
(3 \cdot 0) /(5 \cdot 7)\end{array}$ & $\begin{array}{l}56 \\
(2 \cdot 5)\end{array}$ & $\begin{array}{l}118 / 86 \\
(3 \cdot 5) /(2 \cdot 5)\end{array}$ \\
\hline & $800 \mu \mathrm{g}$ & & & $\begin{array}{l}44 \\
(2 \cdot 7)\end{array}$ & $\begin{array}{l}143 / 104 \\
(4 \cdot 2) /(3 \cdot 3)\end{array}$ \\
\hline & $1600 \mu \mathrm{g}$ & & & $\begin{array}{l}39 \\
(0.8)\end{array}$ & $\begin{array}{l}174 / 120 \\
(6 \cdot 3) /(2 \cdot 2)\end{array}$ \\
\hline
\end{tabular}




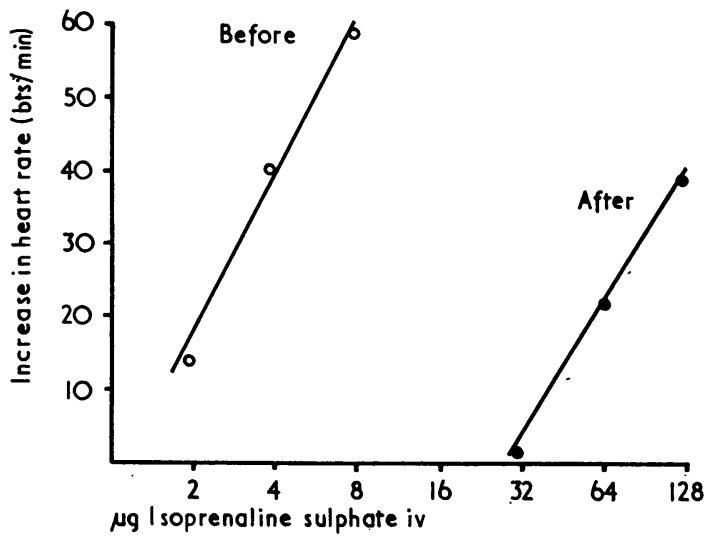

Fig. 3 Mean isoprenaline-induced increases in heart rate before $(O)$ and after (O) intravenous labetalol $(1.5 \mathrm{mg} / \mathrm{kg})(\mathrm{n}=6)$.

influenced the responses. This was not so and, therefore, all values were pooled. Before labetalol the mean increase in sytolic pressure after the cumulative dose of phenylephrine was $69(6 \cdot 8)$ $\mathrm{mmHg}$ (Table 2), whereas to induce similar maximum increases in systolic pressure after labetalol $(1.5 \mathrm{mg} / \mathrm{kg})$ the dose of phenylephrine had to be quadrupled. The log dose phenylephrine response curves of increasing systolic pressure before and after labetalol (Fig. 6) showed a parallel shift to the right after the drug. Again from the regression lines it was calculated that after labetalol the dose of

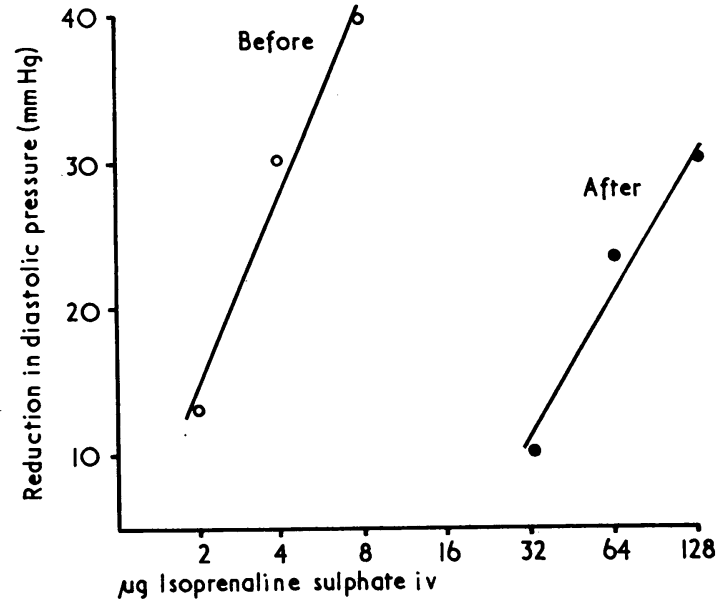

Fig. 4 Mean isoprenaline-induced reductions in diastolic pressure before $(O)$ and after (O) intravenous labetalol (1.5 mg/kg) $(n=6)$.

phenylephrine to produce similar increases in systolic pressure had to be increased by a mean of 3.8 and this was defined as the phenylephrine dose ratio.

In the 3 other subjects there were also parallel shifts of the post-labetalol log dose phenylephrine response curves (Fig. 7). After labetalol $40 \mathrm{mg}$, the phenylephrine dose ratio was 2.4 and after $160 \mathrm{mg}$ it increased to $3 \cdot 8$.

In order to estimate the relation between the

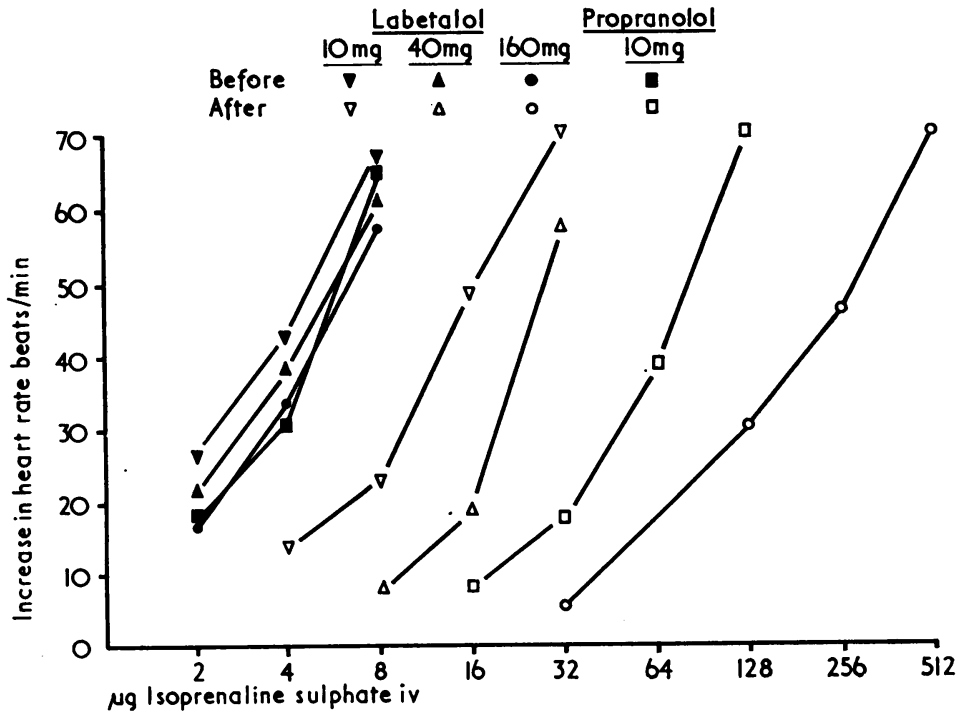

Fig. 5 Mean isoprenaline-induced increases in heart rate before and after intravenous labetalol $10 \mathrm{mg}(\nabla \nabla)$, $40 \mathrm{mg}(\Delta \triangle), 160 \mathrm{mg}(\mathrm{O})$ ), and intravenous propranolol $10 \mathrm{mg}(\square \square)(n=3)$. 


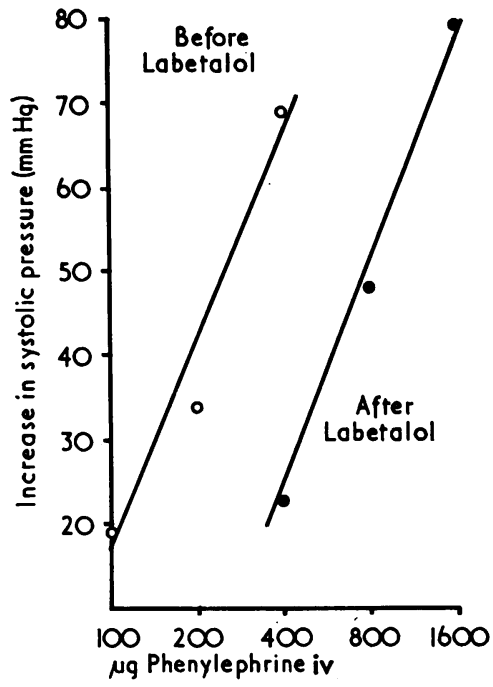

Fig. 6 Mean phenylephrine-induced increases in systolic pressure before $(O)$ and after $(O)$ intravenous labetalol $(1.5 \mathrm{mg} / \mathrm{kg})(\mathrm{n}=6)$.

alpha adrenoceptor blocking component with that of its beta adrenoceptor blocking component, the ratio of alpha: beta antagonist effects was calculated from: isoprenaline dose ratio phenylephrine dose ratio

In the series of six subjects the values were $\frac{26 \cdot 2}{3 \cdot 8}$ 3.8 , thus the mean ratio of alpha: beta antagonist effect was 1:6.9. Thus the alpha blocking com-

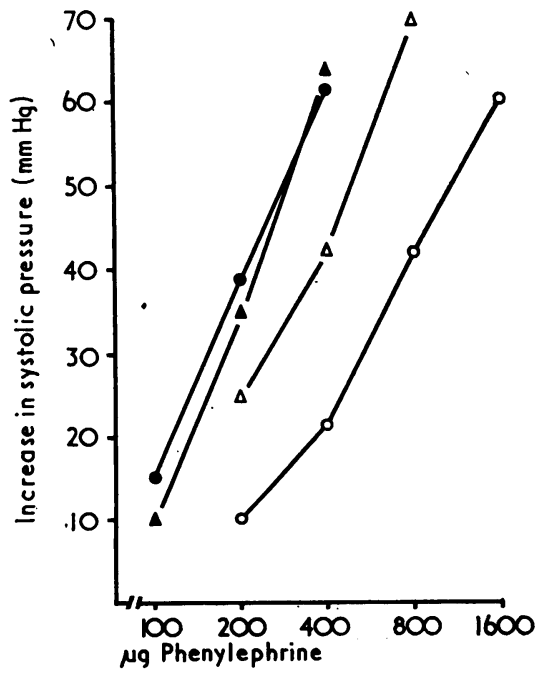

Fig. 7 Mean phenyleprine-induced increases in systolic pressure before and after intravenous labetalol $40 \mathrm{mg}$ $(\Delta \Delta)$ and $160 \mathrm{mg}(\bigcirc \circ)(n=3)$. ponent is approximately one-seventh less potent than the beta component under the circumstances. In the series of three subjects the ratios after $40 \mathrm{mg}$ labetalol were $1: 2.5$ and after $160 \mathrm{mg} 1: 9 \cdot 8$.

EFFECTS OF LABETALOL AND

PROPRANOLOL UPON TILT AND VALSALVA TACHYCARDIA

Before drug administration, tilting was associated with little change in mean arterial pressure after either one or two minutes (Table 3) but resulted in a mean increase in heart rate of 14 to 21 beats/minute after 1 minute and 18 to 20 beats/minute after 2 minutes of tilt. The effects upon blood pressure after labetalol were dose related; the high dose inducing mean reductions in systolic pressure of 8.8 and $10.2 \mathrm{mmHg}$ at 1 and 2 minutes, respectively, compared with predrug values. Propranolol produced only small reductions in systolic pressure of 2.4 and $2.3 \mathrm{mmHg}$, respectively. The administration of both labetalol and propranolol was associated with an inhibition of tilt tachycardia. Propranolol $10 \mathrm{mg}$ produced approximately a 50 per cent reduction compared with the predrug values whereas labetalol produced smaller reductions at all doses. In contrast, labetalol inhibited the tachycardia induced by the Valsalva manoeuvre to a greater extent and this was dose related. The highest dose produced 90 per cent inhibition compared with predrug values while propranolol produced a 57 per cent reduction.

\section{Discussion}

Rosei et al. (1975), Prichard et al. (1975), Koch (1976), and Pearson and Havard (1976) have shown that intravenously administered labetalol in doses of $0.5-2 \mathrm{mg} / \mathrm{kg}$ reduced blood pressure in hypertensive patients. The optimum doses to obtain abrupt reductions in blood pressure in the treatment of hypertensive crises appears to lie between 1.0 and $2 \mathrm{mg} / \mathrm{kg}$. In our own study we showed that intravenous labetalol $1.5 \mathrm{mg} / \mathrm{kg}$ produced an immediate reduction in blood pressure in normotensive subjects. The accompanying small increase in heart rate was presumably related to parasympathetic withdrawal, consequent upon the reduction in blood pressure. This relatively small increase in heart rate after labetalol contrasts with the much larger increases in heart rate usually seen after diazoxide administration (Prichard et al., 1975) and this is presumably the result of the additional beta adrenoceptor inhibitory effect of labetalol. After graded exercise 100 minutes after intravenous labetalol administration the drug significantly inhibited the increase in heart rate and blood pressure 
Table 3 Effects upon mean arterial pressure and mean heart rate induced by tilting and the Valsalva manoeuvre before and after propranolol and labetalol $(n=3)$

\begin{tabular}{|c|c|c|c|c|c|c|c|c|c|c|c|c|c|c|c|c|c|}
\hline & \multicolumn{6}{|c|}{ Mean arterial pressure $(m m H g)( \pm S E)$} & \multicolumn{8}{|c|}{ Change in heart rate after tilting (beats/min) $( \pm S E)$} & \multicolumn{3}{|c|}{$\begin{array}{l}\text { Change in heart rate } \\
\text { after Valsalva (beats) } \\
\text { min) }( \pm S E)\end{array}$} \\
\hline & $\begin{array}{l}\text { Before } \\
\text { Tilt } \\
\text { Before }\end{array}$ & $\begin{array}{l}d r u g \\
\min \end{array}$ & $2 \min$ & $\begin{array}{l}\text { After } \\
\text { Tilt } \\
\text { Before }\end{array}$ & $\begin{array}{l}\text { drug } \\
1 \mathrm{~min}\end{array}$ & $2 \min$ & $\begin{array}{c}\text { Befor } \\
\text { Tilt } \\
\text { Before }\end{array}$ & $\begin{array}{l}\text { e drug } \\
1 \mathrm{~min}\end{array}$ & $2 \min$ & $\begin{array}{l}\text { After } \\
\text { Tilt } \\
\text { Before }\end{array}$ & $\begin{array}{l}\text { drug } \\
1 \mathrm{~min}\end{array}$ & $\begin{array}{l}\% \text { re- } \\
\text { duction }\end{array}$ & $2 \min$ & $\begin{array}{l}\text { \% re- } \\
\text { duction }\end{array}$ & $\begin{array}{l}\text { Before } \\
\text { drug }\end{array}$ & $\begin{array}{l}\text { After } \\
\text { drug }\end{array}$ & $\begin{array}{l}\% \text { re- } \\
\text { duction }\end{array}$ \\
\hline $\begin{array}{l}\text { Propranolol } \\
10 \mathrm{mg} \\
\text { Labetalol } \\
10 \mathrm{mg} \\
40 \mathrm{mg} \\
160 \mathrm{mg}\end{array}$ & $\begin{array}{l}80 \\
(3 \cdot 2) \\
83 \\
(3 \cdot 1) \\
78 \\
(4 \cdot 0) \\
79 \\
(3 \cdot 2)\end{array}$ & $\begin{array}{l}-1 \\
(3 \cdot 4) \\
+3 \\
(3 \cdot 7) \\
0 \\
(4 \cdot 1) \\
+2 \\
(2 \cdot 7)\end{array}$ & $\begin{array}{l}0 \\
(2 \cdot 8) \\
+5 \\
(3 \cdot 4) \\
+2 \\
(3 \cdot 8) \\
+3 \\
(2 \cdot 9)\end{array}$ & $\begin{array}{l}81 \\
(4 \cdot 0) \\
83 \\
(3 \cdot 2) \\
76 \\
(3 \cdot 0) \\
77 \\
(2 \cdot 5)\end{array}$ & $\begin{array}{l}+1 \\
(3 \cdot 7) \\
-1 \\
(3 \cdot 6) \\
-1 \\
(3 \cdot 6) \\
-4 \\
(3 \cdot 9)\end{array}$ & $\begin{array}{l}+4 \\
(3 \cdot 4) \\
+1 \\
(2 \cdot 9) \\
-1 \\
(4 \cdot 0) \\
-6 \\
(3 \cdot 7)\end{array}$ & $\begin{array}{l}65 \\
(3 \cdot 7) \\
64 \\
(2 \cdot 9) \\
62 \\
(3 \cdot 1) \\
64 \\
(2 \cdot 8)\end{array}$ & $\begin{array}{c}+14 \\
(3 \cdot 4) \\
+15 \\
(3 \cdot 1) \\
+21 \\
(2 \cdot 8) \\
+15 \\
(2 \cdot 6)\end{array}$ & $\begin{array}{r}+18 \\
(4.5) \\
+20 \\
(3.5) \\
+20 \\
(2.7) \\
+18 \\
(2.9)\end{array}$ & $\begin{array}{l}60 \\
(2 \cdot 7) \\
68 \\
(3 \cdot 1) \\
72 \\
(3 \cdot 1) \\
76 \\
(2 \cdot 9)\end{array}$ & $\begin{array}{c}+7 \\
(1.9) \\
+12 \\
(2.4) \\
+17 \\
(2.6) \\
+12 \\
(2.3)\end{array}$ & $\begin{array}{l}50 \\
20 \\
19 \\
20\end{array}$ & $\begin{array}{l}+9 \\
(1.9) \\
+15 \\
(2.0) \\
+16 \\
(2.3) \\
+11 \\
(1.8)\end{array}$ & $\begin{array}{l}50 \\
25 \\
20 \\
38\end{array}$ & $\begin{array}{l}+19 \\
(2 \cdot 6) \\
+31 \\
(5 \cdot 4) \\
+29 \\
(3 \cdot 6) \\
+31 \\
(3 \cdot 4)\end{array}$ & $\begin{array}{l}+8 \\
(2 \cdot 0) \\
+16 \\
(3 \cdot 5) \\
+8 \\
(2 \cdot 1) \\
+2 \\
(1 \cdot 8)\end{array}$ & $\begin{array}{r}57 \\
48 \\
72\end{array}$ \\
\hline
\end{tabular}

normally accompanying exercise. There appeared to be a greater effect upon blood pressure than upon heart rate; these observations, coupled with the other immediate cardiovascular effects observed, are consistent with those resulting from combined alpha and beta adrenoceptor antagonism.

In our studies we infused isoprenaline in order to produce exogenous cardiac $\left(\beta_{1}\right)$ and peripheral $\left(\beta_{2}\right)$ adrenoceptor stimulation. The substantial parallel shifts of the isoprenaline log dose-response curves indicate that labetalol is a non-selective competitive beta adrenoceptor blocking drug. Using phenylephrine as an exogenous alpha adrenoceptor stimulant, we showed that after labetalol there were parallel shifts of the log dose-response curves indicative of competitive alpha adrenoceptor antagonism.

In order to construct log-dose response curves of phenylephrine-induced pressor responses in the subjects in our study, it was necessary to use doses up to $400 \mu \mathrm{g} /$ minute in order to obtain values that could be plotted on the straight part of the sigmoid dose response curve. Lower doses than those used provide points on the lower plateau of the sigmoid curve and a plateau of this type is an unreliable index of agonist activity. In order to induce similar increments in blood pressure after labetalol it was necessary to increase the dose up to $1600 \mu \mathrm{g} /$ minute which leads to a somewhat greater pressor response than in the prelabetalol phase. This response was not greater than the systolic pressure increase induced by exercise in these subjects on other occasions and thus phenylephrine-induced increases were within levels seen during normal physiological stresses.

Since six subjects in this study had previously been studied under very similar conditions before and after oral labetalol (Richards et al., 1976), we have compared these data with the results in the present study. After $400 \mathrm{mg}$ oral labetalol the isoprenaline dose ratio was $9 \cdot 63$, whereas after intravenous labetalol (average dose $113 \mathrm{mg}$ ), this increased to $26 \cdot 2$, suggesting that by this route the drug is approximately three times more potent. However, after oral and intravenous labetalol the phenylephrine dose ratios were 3.36 and 3.80 , respectively, suggesting little difference in potency. Estimates of relative potency aipha:beta based upon these data were approximatetly $1: 3$ after oral labetalol and approximately 1:7 after intravenous labetalol.

As the dose of labetalol was increased the isoprenaline dose response curves were also shifted progressively to the right. This observation is consistent with previous studies of beta adrenoceptor antagonist drugs where isoprenaline has been used as the beta agonist (Conway et al, 1976; Aellig, 1976).

The post labetalol phenylephrine dose response curves were also shifted progressively to the right as the dose of labetalol was increased but the shifts in these cases were much less pronounced. Thus, the higher the dose of labetalol the greater became the separation between the alpha: beta antagonist effects. From these it might be assumed that the manifestation of high doses of labetalol in man would be predominantly those known to be associated with beta adrenoceptor antagonists. However, the immediate effect of $1.5 \mathrm{mg} / \mathrm{kg}$ labetalol intravenously was a pronounced reduction in blood pressure and a concomitant small increase in heart rate. This is quite unlike the response seen after the acute administration of a beta adrenoceptor blocking drug such as propranolol (Prichard et al., 1975). A dose of $1.5 \mathrm{mg} / \mathrm{kg}$ is associated with a degree of alpha blockade that is clinically significant.

Other cardiovascular effects consistent with an alpha blocking effect are the immediate reduction in 
blood pressure, the dose-related reduction in mean arterial pressure during tilting and the relatively modest inhibition of tilt tachycardia which appeared to be influenced by the alteration of blood pressure.

Comparing all these data it is possible to assess the relative potency of propranolol and labetalol. The inhibition of tilt tachycardia by labetalol was modified by the drug's effect upon mean arterial pressure, leading to the possibly erroneous conclusion that propranolol was at least 16 times more active. On the other hand, the inhibition of Valsalva tachycardia, probably a fairly good indicator of myocardial beta adrenoceptor blockade, suggests that propranolol was approximately three times more active. This approximation was more consistent with the estimate of potency ratio obtained from studies of isoprenaline-induced tachycardia where the ratio was approximately $6: 1$.

We conclude that labetalol administered intravenously possesses combined alpha and beta adrenoceptor antagonist properties, confirming our previously reported studies with oral labetalol, and that these properties are sufficient to explain the therapeutic effect of intravenous labetalol in hypertension.

\section{References}

Aellig, W. H. (1976). $\beta$-adrenoceptor blocking activity and duration of action of pindolol and propranolol in healthy volunteers. British fournal of Clinical Pharmacology, 3, 251.

Boakes, A. J., Knight, E. J., and Prichard, B. N. C. (1971). Preliminary studies of the pharmacological effects of 5- (1-hydroxy-2-((1-methyl-3-phenylpropyl) amino) ethyl) salicylamide (AH 5158) in man. Clinical Science, 40, 18.

Conway, F. J., Fitzgerald, J. D., McAinsh, J., Rowlands, D. J., and Simpson, W. T. (1976). Human pharmacokinetic and pharmacodynamic studies on atenolol (ICI 66082), a new cardioselective beta adrenoceptor blocking drug. British fournal of Clinical Pharmacology, 3, 267.

Edwards, R., and Raftery, E. B. (1976). Haemodynamic responses after chronic oral treatment with labetalol. British fournal of Clinical Pharmacology, 3, 733.

Farmer, J. B., Kennedy, I., Levy, G. P., and Marshall, R. J. (1972). Pharmacology of AH 5158 a drug which blocks both $\alpha$ and $\beta$ adrenoceptors. British Fournal of Pharmacology, 45,660 .

Koch, G. (1976). Acute haemodynamic effects of an alpha and beta receptor blocking agent (AH 5158) on the systemic and pulmonary circulation at rest and during exercise in hypertensive patients. American Heart fournal. In the press.

Pearson, R. M., and Havard, C. W. H. (1976). Action of intravenous labetalol in hypertensive patients treated with beta adrenoceptor blocking drugs. British fournal of Clinical Pharmacology, 3, 795.

Prichard, B. N. C., Thompson, F. O., Boakes, A. J., and Joekes, A. M. (1975). Some haemodynamic effects of compound AH 5158 compared with propranolol, propranolol plus hydrallazine and diazoxide: the use of AH 5158 in the treatment of hypertension. Clinical Science and Molecular Medicine, 48, 975.

Richards, D. A., Tuckman, J., and Prichard, B. N. C. (1976). Assessment of alpha and beta adrenoceptor blocking actions of labetalol. British fournal of Clinical Pharmacology, 3, 849.

Rose, G. A., Holland, W. W., and Crawley, E. A. (1964). A sphygmomanometer for epidemiologists. Lancet, 1, 296.

Rosei, E. A., Brown, J. J., Trust, P. M., Lever, A. F., and Robertson, J. I. S. (1975). Intravenous labetalol in severe hypertension. Lancet, 2, 1093.

Requests for reprints to Dr. D. A. Richards, Allen and Hanburys Research Ltd., Priory Street, Ware, Hertfordshire SG12 0DJ. 